\title{
Farklı Toprak İșleme Yöntemlerinin Killi Toprağın Bazı Fiziksel Özellikleri Üzerine Etkilerinin Jeoistatistiksel Yöntemle Değerlendirilmesi
}

\author{
Mustafa SAĞLAM ${ }^{*}$ Orhan DENGiZ' $\quad$ K. Çağatay SELVi² $\quad$ E. Fatma GÜRSOY' Çağla ATASOY \\ 'Ondokuz Mayıs Üniversitesi, Ziraat Fakültesi, Toprak Bilimi ve Bitki Besleme Bölümü, Samsun \\ ${ }^{2}$ Ondokuz Mayıs Üniversitesi, Ziraat Fakültesi, Tarım Makinaları Bölümü, Samsun \\ ${ }^{3}$ Ankara Üniversitesi, Ziraat Fakültesi, Toprak Bilimi ve Bitki Besleme Bölümü, Ankara
}

\begin{abstract}
*Sorumlu yazar e-posta (Corresponding author e-mail): mustafa.saglam@omu.edu.tr
Geliș tarihi (Received) :07.11.2013

Kabul tarihi (Accepted) : 03.03.2014
\end{abstract}

Öz

Bu çalıșmada, ağır killi tekstüre sahip bir toprakta farklı toprak ișleme uygulamalarının toprakların havalanma ve su iletimi ile ilișkili fiziksel toprak özellikleri üzerine etkilerinin jeoistatistiksel yöntemle araștırılması amaçlanmıștır. Deneme, 2011 ve 2012 yıllarında Samsun ilinde Karadeniz Tarımsal Araștırma Enstitüsü arazilerindeki 11 m x 50 m boyutlarında hazırlanan parsellerde iki yıl süreyle yürütülmüștür. İk yıl tüm toprak ișleme uygulamalarının toplam porozite, mikropor, hacim ağırlığı ve organik madde içeriği üzerine etkileri istatistiksel olarak önemli bulunmuștur. Toprakların toplam porozite ve mikropor içeriği, toprak ișleme uygulamarıyla artıș gösterirken, toprakların hacim ağırlığı ve organik madde içeriklerinde toprak ișlemeye bağlı azalmaların meydana geldiği görülmüștür. İkinci yı ise toprak ișleme uygulamalarının yalnızca makropor ve mikropor içeriğine etkileri istatistiksel olarak önemli bulunmuș, ancak mikropor içeriğindeki etkiler yıllara göre ters yönde değișkenlik göstermiștir. İkinci yılda toprak ișleme uygulamalarının etkilerindeki değișkenlikler, 2012 yılındaki yağıș miktarlarındaki artıș ile açıklanmıștır. Toprakların her iki yılda da genelde toprak ișleme uygulamalarıyla birlikte bitki gelișimi ve iyi drenaj için uygun makropor içeriklerine sahip olamadığı görülmüștür. Ayrıca Duncan çoklu karșılaștırma sonuçları ile Krigleme haritalarının önemli benzerlikler gösterdiği ve jeoistatistiksel yöntemlerin toprak yönetim uygulamalarına bağlı olarak toprak özelliklerindeki değișkenliklerin haritalanmasında bașarılı bir șekilde kullanılabildiği görülmüștür.

Anahtar Kelimeler: Hacim ağılığı, killi toprak, toplam porozite, toprak ișleme, jeoistatistik

\section{Assessment with Geostatistical Method for Effects of Different Soil Tillage Systems on Clay Soil's Some Physical Properties}

\begin{abstract}
The main aim of this research is to investigate effects of different soil tillage applications on soil physical properties related to soil aeration and water conductivity in soils having heavy soil texture using geostatistical method. Experiment was conducted on $11 \mathrm{~m} \times 50 \mathrm{~m}$ sized plots located in Black Sea Agricultural Research Institute-Samsun between 2011 and 2012 years. It was found significant as statistically effects of all soil tillage applications on total porosity, micropore, bulk density and organic matter content for first year. It was showed that total porosity and micropore content of soils increased
\end{abstract}


with applications of soil tillage whereas, bulk density and organic matter content decreased with the same applications. As for in second years, it was found statistically significant only for micro and macropore contents of soils under these applications. On the other hand, effects on micropore content of soils were showed inversely by taking into consideration of time. Variability of soil tillage effects for second years on it were explained with increasing amount of precipitation in 2012. It was determined that soils have not suitable macrospores for plant growth and for drainage under soil tillage applications in for both years. In addition, it was found the similarity between Duncan multiple comparison results and Kriging maps. Therefore, geostatistic methods can be used successfully for mapping of variations of soil properties depending at some soil management applications

Key Words: Bulk density, clay soil, total porosity, soil tillage, geostatistics,

\section{Gíriș}

Tarımsal üretimde öncelikli amaç, çevre ile uyumlu yönetim uygulamaları ve girdilerinin kullanııdığı yöntemlerle yetiștiricilik yapmak olmalıdır. Özellikle karasal ekosistemlerde tarımsal üretimin sürdürülebilir kılınabilmesi için toprak üzerinde yaratılan değișimlerinde iyi bir șekilde incelenmesi gerekir. Çevreye zarar vermeden sürüdürülebilir ürün yetiștiriciliği yapabilmek ancak, topraklar konusunda ortaya konabilecek oldukça fazla bilgi birikimiyle sağlanabilir. Bu kapsamda, sürdürülebilir tarım kavramı 1980'li yıllardan sonra tarımsal üretimle ilgili yapılan bilimsel çalıșmalarda yüksek sesle dile getirilmeye bașlanmıștır (Kirișçi vd., 1999). Tarımsal ürünlerin geçmiște öncelikli olarak insan beslenmesi temel alınarak yetiștirilmesine karșın, günümüzdeki teknolojik gelișimlerle birlikte sanayi hammaddesi olarak da önemli miktarlarda pay almaya bașlaması, tarımsal sürdürülebilirliliği daha anlamlı ve önemli kılmaya bașlamıștır. Ancak, tarımsal ürünlerin bu değer artıșıla birlikte, sanayinin yüksek taleplerinin karșılanmasına yönelik sürdürülebilir tarım sistemlerinde ortaya çıkan tarımsal yoğunluğunda, çevresel kaliteyi olumsuz yönde etkilediği görüșü karșı bir düșünce olarak son dönemlerde oldukça yaygın șekilde ifade edilmektedir. Tarım alanların yoğun kullanımlarıyla birlikte toprak özelliklerinde ortaya çıan zamana ve mesafeye bağlı bu değișimler, günümüzde toprakların sürdürülebilir kullanımlarının gözden geçirilmesini zorunlu kılmaktadır. Kullanım ve yönetim nedeniyle toprak özelliklerindeki değișimler ile onların çevre ve verimlilik kapasitesi üzerine olan etkileri birçok araștırmacı tarafından yapılan çalıșmalarla da ortaya konulmuștur (Lal ve Stewart, 1990; Arzeno, 1990; Alves, 1992; Paz-Gonzalez ve Guerif, 1993; Sarvasi, 1994; Castro, 1995; Fernandez-Rueda ve PazGonzalez, 1998).

Gerek geleneksel tarım gerekse organik tarım sistemlerinde bitkisel üretim faaliyetleri toprak ișleme ile bașlar. Söz konusu bitkisel üretim sistemlerindeki toprak ișleme, iyi bir tohum yatağı hazırlığı, toprağın fiziksel durumunun iyileștirilmesi ve yabancı ot kontrolünün sağlanması gibi birincil amaçların yanı sıra, toprağın gevșetilmesi, ufalanması, keseklerin parçalanması, kaymak tabakasının kırıması, tohum yatağının bastırıması, toprağın su tutma kapasitesinin artırılması ve devamlılığının sağlanmassı, erozyonun önlenmesi ile gübre ve diğer maddelerin toprağa karıștırılması gibi ikinci derece amaçlara da hizmet etmektedir (Korucu, 2002). Özellikle tohum yatağı hazırlarken, tohumun çimlenmesini sağlayacak gevșek bir ortam hazırlamak, bitki köklerinin gelișmesine uygun su ve hava düzenine sahip bir toprak ortamı sağlamak, toprak ișlemenin öncelikli amacıdır. Diğer bir ifadeyle toprak ișleme ile, bitkinin gelișmesine uygun bir strüktür temin edilmektedir (Çetin vd., 2009).

Toprak ișlemeyle bitki gelișimi için uygun strüktür kazandırılan toprakta, toprağa ait fiziksel, kimyasal ve morfolojik özellikler kullanılarak toprağın ișlendiği ve ișlenmediği alanlar karșılaștırılabilir veya sürekli toprak ișlemenin etkileri değerlendirilebilir. Örneğin așırı toprak ișleme sonucunda toprak organik maddesinde ortaya çıkan azalmalar, toprağın fiziksel ve kimyasal verimliliğinin sınırlanmasına neden olabillir. Diğer taraftan toprak șartlarındaki bu değișimler, besin/beslenme dinamiklerini ve biyolojik aktiviteyi etkileyerek ürün verimi üzerine önemli etkiler ortaya koyabilir (Salinas-Garcia vd., 1997). Çünkü agregatlașma ve porozite gibi fiziksel toprak özellikleri nem içeriği, sıcaklık, havalanma ve mekaniksel direnç gibi diğer toprak özellikleri üzerine olan dolaylı etkileriyle bitki gelișimini etkilemekte (Ferreras vd., 2000), benzer șekilde toprak porozitesinin özellikle de makro ve mikroporların dağıımıda, köklere karșı toprak direncini ve yarayıșlı suyu düzenleyerek bitkilerin gelișimini büyük ölçüde etkileyebilmektedir (Farkas vd., 2006; Lipiec vd., 2006; Witkowska-Walczak ve Turski, 2004). 
Toprakların por büyüklük dağılımı, toprak ișlemeden büyük ölçüde etkilenmektedir. Lipiec vd. (2006), geleneksel toprak ișleme altındaki toprakların genel olarak daha düșük hacim ağırlığına sahip olduğunu ve pulluk katmanı içerisindeki toplam poroziteninde sıfır toprak ișleme altındaki topraklara göre daha yüksek bir ilișki ortaya koyduğunu bildirmektedir. Toplam porozitedeki değișimler por büyüklük dağılımındaki değișimlerle ilișkilidir ancak bu ilișki toprak tekstürüne göre değișebilmektedir. Schjønning ve Rasmussen (2000), aynı koșullar altında sıfir toprak ișleme ile geleneksel toprak ișlemenin etkilerini karșılaștırdıkları çalıșmada, sıfır toprak ișleme altında kumlu ve siltli tın toprakların daha düșük makropor hacmine sahip olduğunu, buna karșın kumlu tın topraklarda tersi bir durumun olduğunu bildirmektedir. Kay ve Vanden Baygaart (2002) ise geleneksel toprak ișlemeden sıfır toprak ișlemeye doğru dönüldüğünde genel olarak 100$150 \mu \mathrm{m}$ büyüklüğündeki por hacminin arttığını ve 30-100 $\mu \mathrm{m}$ büyüklüğündeki por hacminin de azaldığını ifade etmektedir. Yine ișlenen ve ișlenmeyen topraklar karșilaștıııldığında toprakların su iletim özellikleri üzerine yönetim ve toprak ișlemenin değișik etkilerinin olduğunu gösteren birçok çalıșmada mevcuttur (Gantzer ve Blake, 1978; Freebarin vd., 1986; Ankeny vd., 1990; Arshad vd., 1999; Gomez vd., 1999; Rasmussen, 1999; McGarry vd., 2000).

2011 ve 2012 yıllarında Samsun Karadeniz Tarımsal Araștırma Enstitüsü arazisinde yürütülen bu çalıșmayla, yoğun ișlemeli tarım yapılan alanlarda toprak ișlemenin toprakların sürdürülebilir boșluk dağılımları üzerine etkilerinin araștırılması amaçlanmıștır. Killi tekstüre sahip bir toprakta farklı toprak ișleme aletlerinin ve yöntemlerinin (Pulluk + 2*Diskaro + 2*Freze; Ağır çizel + 2* Diskaro $+2 *$ Freze; pulluk + 2*Freze; Doğrudan ekim) toprakların hacim ağırlığı, organik madde, toplam porozite, mikro ve makropor dağıımları üzerine olan etkileri klasik istatistik ve jeoistatistiksel yöntemlerle değerlendirilmiștir.

\section{MATERYAL VE YÖNTEM}

Çalıșma Samsun ili Karadeniz Tarımsal Araștırma Enstitüsü arazilerinde iki yıllık arazi denemesi șeklinde yürütülmüștür. Deneme alanına ait bazı toprak özellikleri Çizelge l'de, denemenin yürütüldüğü yılllara ait aylık toplam yağıș ve ortalama sıcaklık değerleri ise Çizelge 2'de verilmiștir.

Çizelge 1. Deneme toprağının bazı fiziksel ve kimyasal özellikleri

Table 1. Some physical and chemical properties of selected soil

\begin{tabular}{cccccc}
\hline Kil & Silt & Kum & Bünye sınıfı & pH & EC \\
\hline 67,03 & 18,16 & 14,81 & Kil & 7,22 & 0,64 \\
\hline
\end{tabular}

Çizelge 2. 2011 ve 2012 yıllarına ait aylık ve yıllık toplam yağıș ve ortalama sıcaklık değerleri

Table 2. Total precipitation and average temperature values of monthly and annual for 2011 and 2012 years

\begin{tabular}{lccccc}
\hline \multirow{2}{*}{ Aylar } & \multicolumn{2}{c}{2011} & & \multicolumn{2}{c}{2012} \\
\cline { 2 - 3 } \cline { 5 - 5 } & Yağıș $(\mathrm{mm})$ & Sıcaklık $\left.{ }^{0} \mathrm{C}\right)$ & & Yağıș $(\mathrm{mm})$ & Sıcaklık $\left(^{0} \mathrm{C}\right)$ \\
\hline Șubat & 117,2 & 5,7 & 98,0 & 5,4 \\
Mart & 45,4 & 7,4 & 70,8 & 3,2 \\
Nisan & 95,6 & 9,7 & 81,6 & 5,8 \\
Mayıı & 60,6 & 14,8 & & 10,4 & 13,3 \\
Haziran & 66,1 & 20,1 & 34,4 & 17,5 \\
Temmuz & 49,6 & 23,9 & & 24,4 & 21,9 \\
Ağustos & 26,0 & 23,1 & 96,0 & 24,0 \\
Eylül & 14,2 & 20,1 & 179,6 & 23,0 \\
Ekim & 39,1 & 17,8 & 113,0 & 20,1 \\
Kasım & 135,5 & 13,5 & 99,8 & 17,8 \\
Aralık & 149,5 & 9,2 & & 276,4 & 13,5 \\
Toplam Yağıș & 64,4 & - & 128,6 & 9,2 \\
Ortalama Sıcaklık & 863,2 & - & 11,5 & 1211,0 & - \\
\hline
\end{tabular}


2011 ve 2012 yıllarında 11 m x 50 m (550 m²) boyutlarında olușturulan 5 parselde yürütülen denemede, 4 farklı toprak ișleme (i - Pulluk + $2{ }^{*}$ Diskaro $+2{ }^{*}$ Toprak frezesi + Ekim makinası; iiAğır çizel $+2{ }^{*}$ Diskaro $+2{ }^{*}$ Toprak frezesi + Ekim makinasl; iii- Pulluk $+2^{*}$ Toprak frezesi + Ekim makinası; iv- Doğrudan ekim) ve kontrol konuları araștırılmıștır. Her iki yılda da toprak ișleme konularının uygulandığı parsellerde toprak ișleme sonrasında mısır bitkisi yetiștirilirken kontrol parselinde toprak ișleme ve bitkisel üretime yönelik hiçbir uygulama yapılmamıștır. Her iki yılda da toprak fiziksel özellikleri üzerine toprak ișleme yöntemlerinin etkisinin incelenmesine yönelik toprak örneklemesi parsellerdeki mısır bitkisi hasat edildikten sonra bozulmuș ve bozulmamıș toprak örneklemesi șeklinde 0-30 cm derinlikten yapılmıștır.

Alınan bozulmamıș toprak örneklerinde hacim ağırlığı; Blake ve Hartge (1986)'a göre, toplam porozite; toprakların hacim ağırlığı ve özgül ağırlığı arasındaki ilișkiler kullanılarak Danielsen ve Sutherland (1986) tarafından bildirilen Eșitlik 1'e göre hesaplanmıștır.

Toplam Porozite $(\%)=1-\frac{\rho_{b}}{\rho_{k}} \boldsymbol{x} 100 \quad\left(\rho_{k}=2.65\right)$

Mikropor miktarl; Klute (1986) tarafından bildirilen tansiyon tablası yöntemine göre, makropor miktarı ise; toplam porozite ile mikropor arasındaki farktan hesaplanmıștır. Bozulmuș toprak örneklerinde ise toplam organik madde; Jackson (1958) tarafından modifiye edilmiș Walkley-Black yöntemine göre, tekstür; Gee ve Bauder (1986) tarafindan bildirilen Bouyoucous hidrometre yöntemine göre, $\mathrm{pH}$; 1:2'lik toprak-su karıșımında Hendershot vd. (1993)'e göre, elektriksel iletkenlik (EC); 1:2'lik toprak-su karıșımında EC metre aleti kullanılarak Rhoades (1986)'e göre, kireç; Allison ve Moodie (1965)'ye göre hacimsel olarak belirlenmiștir.

Analiz edilen toprak özelliklerinin uzaysal değișkenlik bilgisini ortaya koymak amaciyla ise, öncelikle her bir toprak özelliğine ait semivariogram modelleri tahmin edilmiștir. Semivariogram modellerinin tahmininde așağıdaki Eșitlik 2 'den yararlanıımıștır.

$$
\gamma(h)=\frac{1}{2 N} \sum_{i=1}^{N}\left(Z_{x}-Z_{x+h}\right)^{2}
$$

\section{Burada}

Y (h): h uzaklığı için semivaryans,

h: ayırma uzaklığı (lag),

Zx: x noktasında ölçülmüș örnek değeri,

Zx+h: x+h noktasında ölçülmüș örnek değeri,

$\mathrm{N}$ : h ayırma uzaklığı için çiftlerin toplam sayısını tanımlamaktadır.

Toprak özelliklerine ait en uygun semivariogram modeline karar verirken belirleme katsayısını $\left(R^{2}\right)$ en yüksek, hata kareler toplamını (HKT) en düșük ve çapraz doğrulamada regresyon katsayısını (r) en yüksek tahmin eden model, uygun semivariogram modeli olarak seçilmiștir. Daha sonra tahmin edilen semivariogram modelleri kullanılarak krigleme yapılmıș ve bu șekilde çalıșma alanı içerisindeki değișkenlikler haritalanmıștır. Toprak özelliklerine ait semivariogram tahminlerinin ve krigleme haritalarının hazırlanmasında bilgisayarda GS+ 7.0 paket programı kullanılırken, toprak özellikleri arasındaki Duncan çoklu karșılaștırma testlerinde ise SPSS 17.0 paket programı kullanmıștır.

\section{BULGULAR ve TARTIȘMA}

Hacim ağırlığı, toplam porozite, doymuș hidrolik iletkenlik, hava geçirgenliği vb. dinamik toprak fiziksel özelliklerinin değerlendirilmesi fiziksel toprak kalitesi hakkında değerli bilgiler sağlamaktadır. Farkı toprak ișleme yöntemlerinin, toprakta havalanma ve su hareketiyle ilișkili dinamik fiziksel toprak özellikleri üzerine olan etkilerinin incelendiği 2 yıllık arazi denemesinden elde edilen sonuçlarla ilgili tanımlayıcı istatistikler Çizelge 3'de verilmiștir.

Fiziksel toprak özellikleri çarpıklık katsayılarına göre, çalıșmanın yürütüldüğü 2011 ve 2012 yıllarında normal dağılım veya normal dağııma yakın çarpıklıta dağlımlar sergilemișlerdir (Webster, 2001). Yine yillara göre toprak özellikleri değișkenlik katsayısına göre benzer değișkenlikler ortaya koymuș ve toplam porozite, mikropor ve hacim ağırlığı değișkenlik katsayısına göre düșük düzeyde değișkenlikler sergilerken, makropor ve organik maddenin her iki yıldaki değișkenlikleri orta düzeyde olmuștur (Wilding 1994; Mulla ve McBratney 2000). Çalıșmamızda değișkenlik katsayıları ile ilgili elde ettiğimiz bulgulara benzer sonuçlar Campos vd. (2007) ve Campos vd. (2013) tarafından da rapor edilmektedir. Diğer taraftan makropor ve organik maddenin sahip olduğu orta düzeydeki değișkenlik, her iki toprak özelliğine ait veri setlerinde belirli bir düzeyde hetorejenliğin var olduğunu ortaya koymaktadır. 
Çizelge 3. 2011 ve 2012 yıllarında fiziksel toprak özelliklerine ait tanımlayıcı istatistikler

Table 3. Descriptive statistics for soil physical properties in 2011 and 2012 years

\begin{tabular}{lcccccccccc}
\hline Tanımlayıcı & \multicolumn{3}{c}{ Toplam } & Porozite & \multicolumn{2}{c}{ Makropor } & \multicolumn{2}{c}{ Mikropor } & \multicolumn{1}{c}{ Hacim Ağırlığı } & \multicolumn{2}{c}{ Organik Madde } \\
\cline { 2 - 12 } İstatistikler & 2011 & 2012 & 2011 & 2012 & 2011 & 2012 & 2011 & 2012 & 2011 & 2012 \\
\hline Ortalama & 58,34 & 54,80 & 6,56 & 8,94 & 51,75 & 45,51 & 1,10 & 1,20 & 2,46 & 2,30 \\
Standart Sapma & 1,57 & 1,65 & 1,65 & 1,91 & 2,46 & 3,43 & 0,04 & 0,04 & 0,51 & 0,46 \\
En Küçük & 54,90 & 50,93 & 3,15 & 1,38 & 46,77 & 34,42 & 1,00 & 1,07 & 1,79 & 1,04 \\
En Büyük & 62,41 & 59,50 & 10,29 & 14,58 & 57,05 & 58,12 & 1,20 & 1,30 & 3,88 & 3,28 \\
Değișkenlik Katsayısı & 2,68 & 3,01 & 25,13 & 21,34 & 4,75 & 7,54 & 3,49 & 3,76 & 19,14 & 20,07 \\
Çarpıklık & 0,59 & 0,22 & 0,17 & $-0,48$ & $-0,07$ & 0,19 & $-0,51$ & $-0,24$ & 0,35 & $-0,44$ \\
Basıklık & 0,39 & 0,51 & $-0,49$ & 3,88 & $-0,40$ & 3,02 & 0,42 & 0,49 & $-0,60$ & 0,45 \\
\hline
\end{tabular}

Toplam Porozite: \%; Makropor: \%; Mikropor: \%; Hacim Ağırlığı: g cm-3; Organik Madde: \%; Değișkenlik Katsayısı: \%.

2011 ve 2012 yıllarında farklı toprak ișleme yöntemlerinin toprakta havalanma ve su hareketini etkileyen fiziksel toprak özellikleri üzerine olan etkileri istatistiksel olarak değerlendirilmiș ve elde edilen Duncan çoklu karșılaștırma sonuçları Çizelge 4'de verilmiștir. Cizelge 4 incelendiğinde toprak ișleme uygulamalarının fiziksel toprak özellikleri üzerine olan etkilerinin denemenin yürütüldüğü iki yıllık sürede, yıllara göre farklılıklar gösterdiği görülmektedir. Toprak ișleme uygulamalarının yıllara göre farklı șekilde ortaya çıkan etkilerinin, denemenin yürütüldüğü 2011 ve 2012 yıllarının Mayıs ve Ekim ayları arasında bölgede gerçekleșen farklı aylık yağıș rejimi ve yağıș miktarından kaynaklandığı düșünülmektedir (Çizelge 2). Lal (1989), toprak fiziksel özelliklerindeki değișimin büyüklüğünün ve eğilimlerinin geçmiș koșullara, tarla trafiğine, toprak tekstürüne ve iklime bağlı olduğunu bildirmektedir. Çalıșmanın alanı topraklarının kil içeriğinin yüksek ve killi tekstüre sahip olması nedeniyle 2011 ve 2012 yıllarında gerçekleșen farklı yağıș rejimi ve yağıș miktarlarının topraklardaki șișme ve büzülme olaylarında farklılıklar yarattığı ve bunun da yıllara göre toprak ișleme uygulamalarının farklı etkiler meydana getirmesine neden olduğu düșünülmektedir.

Çizelge 4. Toprak ișleme uygulamalarına göre 2011 ve 2012 yıllarında toprak fiziksel özelliklerinin Duncan çoklu karșılaștırma sonuçları

Table 4. The results of Duncan multiple comparison of soil physical properties in 2011 and 2012 years according to soil tillage practices

\begin{tabular}{|c|c|c|c|c|c|}
\hline $\begin{array}{l}\text { Toprak İșleme } \\
\text { Yöntemleri }\end{array}$ & $\begin{array}{c}\text { Toplam Porozite } \\
(\%)\end{array}$ & $\begin{array}{c}\text { Makropor } \\
(\%)\end{array}$ & $\begin{array}{c}\text { Mikropor } \\
(\%)\end{array}$ & $\begin{array}{c}\text { Hacim Ağırlığı } \\
\left(\mathrm{g} \mathrm{cm}^{-3}\right)\end{array}$ & $\begin{array}{c}\text { Organik Madde } \\
(\%)\end{array}$ \\
\hline \multicolumn{6}{|c|}{2011} \\
\hline$P+2^{*} D+2^{*} F$ & $59,60 \pm 0,77$ a & $6,48 \pm 0,66$ & $53,11 \pm 1,05$ a & $1,07 \pm 0,02 \mathrm{~b}$ & $2,64 \pm 0,17 b$ \\
\hline$A C+2^{*} \mathrm{D}+2^{*} \mathrm{~F}$ & $59,11 \pm 0,49 \mathrm{ab}$ & $6,55 \pm 0,59$ & $52,56 \pm 0,76 \mathrm{ab}$ & $1,08 \pm 0,01 a b$ & $2,25 \pm 0,10 b$ \\
\hline$P+2^{*} \mathrm{~F}$ & $57,79 \pm 0,28 b$ & $6,74 \pm 0,60$ & $51,05 \pm 0,64 \mathrm{bc}$ & $1,12 \pm 0,01$ a & $2,34 \pm 0,09 b$ \\
\hline $\mathrm{DE}$ & $57,88 \pm 0,42 b$ & $7,27 \pm 0,71$ & $50,61 \pm 1,07 \mathrm{c}$ & $1,12 \pm 0,01 a$ & $2,58 \pm 0,12 b$ \\
\hline Kontrol & $57,62 \pm 0,39 b$ & $6,83 \pm 0,64$ & $50,79 \pm 0,97 \mathrm{c}$ & $1,12 \pm 0,01$ а & $3,31 \pm 0,14$ a \\
\hline P Değeri & $0,039 *$ & 0,920 & $0,042^{*}$ & $0,034^{*}$ & $<0,001$ ** \\
\hline ODÖ & 0,721 & 0,597 & 0,045 & 0,703 & 0,537 \\
\hline ODD & & & 42,585 & & \\
\hline \multicolumn{6}{|c|}{2012} \\
\hline$P+2^{*} \mathrm{D}+2^{*} \mathrm{~F}$ & $54,32 \pm 0,28$ & $10,37 \pm 0,60$ a & $42,47 \pm 1,11 \mathrm{~b}$ & $1,21 \pm 0,01$ & $2,39 \pm 0,06$ \\
\hline$A C+2^{*} \mathrm{D}+2^{*} \mathrm{~F}$ & $54,65 \pm 0,48$ & $9,48 \pm 0,45 \mathrm{ab}$ & $45,18 \pm 0,70$ а & $1,20 \pm 0,01$ & $2,18 \pm 0,21$ \\
\hline$P+2^{*} F$ & $55,86 \pm 0,34$ & $8,90 \pm 0,26$ abc & $46,96 \pm 0,40 a$ & $1,17 \pm 0,01$ & $1,87 \pm 0,24$ \\
\hline DE & $54,62 \pm 0,59$ & $7,55 \pm 0,68 c$ & $47,08 \pm 1,23$ а & $1,20 \pm 0,02$ & $2,14 \pm 0,16$ \\
\hline Kontrol & $54,76 \pm 0,55$ & $8,34 \pm 0,32 b c$ & $46,13 \pm 0,76$ a & $1,20 \pm 0,02$ & $2,48 \pm 0,14$ \\
\hline P Değeri & 0,227 & $0,003^{* *}$ & $0,004 * *$ & 0,225 & 0,176 \\
\hline ODÖ & 0,117 & 0,125 & 0,441 & 0,119 & 0,756 \\
\hline
\end{tabular}

$\mathrm{P}+2{ }^{*} \mathrm{D}+2{ }^{*} \mathrm{~F}:$ Pulluk+Diskaro+Freze; $A C++2{ }^{*} \mathrm{D}+2{ }^{*} \mathrm{~F}:$ Ağır Çizel+Diskaro+Freze; P+2*F: Pulluk+Freze; DE: Doğrudan Ekim; ODÖ: Ortak Değișken Önemi; ODD: Ortak Değișken Düzeltmesi; *: $p<0,05 ; * *: p<0,01$. 
Toprak ișleme uygulamalarının öncelikle 2011 yılına ait sonuçları değerlendirildiğinde, makropor dıșında incelenen tüm fiziksel toprak özelliklerinde toprak ișleme uygulamalarının önemli değișimler meydana getirdiği görülmektedir. Toplam porozite ve mikropor düzeyleri üzerine Pulluk+Diskaro+Freze ve Ağır Çizel+Diskaro+Freze uygulamalarının hemen hemen benzer bir etkiye sahip olduğu ve bu uygulamalarla 2011 yılında toprakların toplam porozite ve mikropor düzeylerinin arttığı belirlenmiștir. Pulluk+Freze, Doğrudan Ekim ve Kontrol uygulamalarının ise toplam porozite ve mikropor düzeyleri üzerine olan etkilerinin Pulluk+Diskaro+Freze uygulamasının etkisinden tamamen farklı ve uygulamalar arasında benzer bir etkisinin olduğu görülmüștür (Çizelge 4). Hacim ağırlığına ilișkin sonuçlar ise, toprak ișlemeye bağlı olarak topraklarda gözenekliliğin arttığını ve buna bağlı olarak da hacim ağırlığı değerlerinini azaldığını ortaya koymaktadır. Topraklarda yüksek gözenekliliğin göstergesi olarak kabul edilen en düșük hacim ağırlığı değerleri Pulluk+Diskaro+Freze uygulamasında elde edilirken, bu toprak ișleme uygulaması diğer uygulamalara göre toprakta en fazla gözenekliliğinin sağlandığı uygulama olmuștur. Pulluk+Freze, Doğrudan Ekim ve Kontrol uygulamaları ise, toprak sıkıșmasına bağlı olarak 2011 yılında daha yüksek hacim ağırlığına ve daha düșük toprak gözenekliliğine sahip toprak ișleme uygulamaları olmușlardır. Diğer taraftan Ağır Çizel+Diskaro+Freze uygulamasının hacim ağırlığı yönünden tüm toprak ișleme uygulamalarıyla benzer bir etkiye sahip olduğu görülmüștür (Çizelge 4). 2011 yılında toprak organik maddesi yönünden toprak ișleme uygulamalarıyla Kontrol uygulaması karșılaștırıldığında, en yüksek organik madde değerlerinin Kontrol uygulamasında elde edildiği buna karșın toprak ișleme uygulamalarının yürütüldüğü parsellerde organik madde miktarlarının Kontrol uygulamasına göre daha düșük olduğu ve toprak ișlemeyle ortaya çıkan bu farkların istatistiksel olarak önemli olduğu belirlenmiștir. Yani toprak ișlemenin yapıldığı tüm parsellerde Kontrol uygulamasına göre organik madde miktarında istatistiksel olarak önemli azalmaların meydana geldiği ancak toprak ișleme uygulamalarının toprakların organik madde içeriğine etkilerinin ise benzer olduğu görülmüștür (Çizelge 4).
2012 yılına ait veriler incelendiğinde, toprak ișleme uygulamalarının toprakların yalnızca makropor ve mikropor içerikleri üzerine olan etkilerinin istatistiksel olarak önemli bulunduğu, ancak incelenen diğer fiziksel özellikler yönünden toprak ișleme uygulamalarının etkilerinin istatistiksel olarak önemsiz olduğu görülmüștür (Çizelge 4). Pulluk+Diskaro+Freze uygulaması, topraklarda makropor içeriğini artırırken, mikropor içeriğinin de en düșük bulunduğu toprak ișleme uygulaması olmuștur. Diğer taraftan Doğrudan Ekim uygulaması, en düșük ortalama makropor içeriğine sahip uygulama olmasına karșın Kontrol ve Pulluk+Freze uygulamalarıyla benzer etkiye sahip olduğu, mikropor içeriğinde de Pulluk+Diskaro+Freze uygulaması dıșındaki tüm toprak ișleme uygulamalarının benzer bir etkisinin olduğu belirlenmiștir (Çizelge 4).

Toprak ișleme uygulamalarının toprak fiziksel özellikleri üzerine etkilerine yönelik literatürde bir çok çalıșma olmasına karșın aynı derecede birçok farklı sonucunda verildiği görülmektedir. Yapılan bazı çalıșmalar sıfır toprak ișleme altında așırı toprak sıkıșmasının meydana geldiğini bildirirken (Tebrügge ve Düring, 1999; Oliver vd., 2002; Fabrizzi vd., 2005), bazılarıda toprak sıkıșmasının gözlemlenmediğini bildirmektedir (Logsdon ve Karlen, 2004; Filipovic vd., 2006). Yine pullukla toprak ișleme (Tebrügge ve Düring, 1999) veya azaltılmıș toprak ișleme (Mc Vay vd., 2006) karșısında sıfır toprak ișleme uygulamasının toprakların hacim ağırlığını artırdığı ve aynı zamanda farklı azaltılmıș toprak ișleme uygulamalarının yoğun toprak ișleme uygulamalarıyla kıyaslandığında üst toprak katmanlarında toprak sıkıșmasını artırabileceği (Rasmussen, 1999) ifade edilmektedir. Fabrizzi vd. (2005) ise toprak sıkıșmasının genel olarak sıklıkla meydana geldiğini ancak bu sıkıșmanın sıfır toprak ișleme altında bitkiler üzerine her zaman zararlı bir etkisi olmadığını belirtirken, singh vd. (1992) sınır değer olarak $1.3 \mathrm{gr} \mathrm{cm}^{-3 \prime}$ e eșit veya daha düșük hacim ağırlığına sahip herhangi bir toprağın bitki gelișimini sınırlamadığını ifade etmektedir. Strudley vd. (2008) ise, toprakların hacim ağırlığı ve porozite içeriği üzerine toprak ișleme uygulamalarının tutarsız etkileri olduğunu bildirmektedir. Lal vd. (1994) ve Mahboubi vd. (1993)'da, toprak fiziksel özelliklerini iyileștirmede geleneksel toprak ișlemeye göre çizel ile toprak 
ișleme ve sıfır toprak ișlemeyi içeren uzun süreli koruyucu toprak ișleme yöntemlerinin faydalı etkileri olduğunu ve sıfır toprak ișleme uygulamasında daha düșük hacim ağırlığı ve daha yüksek porozite ve agregatlașma değerleri elde edildiğini bildirmektedir. 2011 yılı sonuçlarımız toplam porozite ve hacim ağırlığı değerleri, toprak ișleme uygulamaları kıyaslandığında Kontrol uygulamasında daha düșük toplam porozite ve daha yüksek hacim ağırlığı değerleri alarak kontrol uygulamasında daha fazla toprak sıkıșmasının olduğunu ortaya koyarken; 2012 yılındaki sonuçlar ise Kontrol ve toprak ișleme uygulamalarının aynı özellikler üzerine tutarsız etkilerinin olduğu görülmüștür. Ancak her iki yıla ait hacim ağırlığı değerleri, gerek kontrol uygulamasında gerekse toprak ișleme uygulamalarında bitki gelișimini sınırlayacak düzeyde bir toprak sıkıșmasının gerçekleșmediğini göstermektedir.

Vidal (1997), sıfır toprak ișlemeyle geleneksel toprak ișlemeyi por büyüklük dağılım değerleri yönünden karșılaștırdığında, geleneksel toprak ișlemede > $20 \mu \mathrm{m}$ porların istatistiksel olarak önemli düzeyde daha büyük bir yüzdeye sahip olduğunu bildirirken doymuș hidrolik iletkenlik ve makroporozitenin dolaylı ölçümlerininde yine geleneksel toprak ișlemede daha yüksek olduğunu rapor etmektedir. Bu çalıșmada da makropor içeriği yönünden 2011 yılında tüm uygulamalara ait sonuçlarda önemli farklılıklar gözlemlenmezken, 2012 yılındaki sonuçlar literatür sonuçlarıyla benzer bulgular ortaya koyarak kontrol uygulamasına kıyasla toprak ișleme uygulamalarının toprakların makropor içeriğini artırdığını ve Pulluk+Diskaro+Freze uygulamasıyla en yüksek değerleri aldığını ortaya koymuștur. Mikropor değerleri ise yıllara göre çelișkili sonuçlar ortaya koymasına karșın 2012 yılında en yüksek makropor içeriğinin bulunduğu Pulluk+Diskaro+Freze uygulamasında en düșük değerini almıș ve bu azalma istatistiksel olarak önemli bulunmuștur. Ayrıca Sparling ve Schipper (2002), geniș makroporlardan hesaplanan makroporozitenin \% 10-15 arasındaki değerlerinin genel olarak bitki gelișimi ve iyi drenaj için uygun olduğunu ifade etmektedir. Buna göre çalıșmanın yürütüldüğü her iki yılda da 2012 yılındaki Pulluk+Diskaro+Freze uygulamasına ait makropor sonuçları dıșındaki tüm makropor değerlerinin bitki gelișimi ve iyi drenaj koșulları için yeterli hacimde olmadığı görülmüștür. Ancak, düșük makropor değerlerinin toprak ișleme uygulamalarının etkisinin yanı sıra çalıșma alanının tekstürü ile de ilișkili olabileceği düșünülmektedir.

Hao vd. (1999), toprağın daha az bozulması ve bitki atıklarının daha düșük ayrıșması nedeniyle minimum toprak ișleme uygulamasında organik madde içeriğinin istatistiksel olarak önemli düzeyde daha yüksek olduğunu ifade ederken, Havlin vd. (1990) ve Franzluebbers vd. (1995), koruyucu toprak ișlemenin 10 yıldan fazla bir süre sonra organik madde içeriğini artırdığını bildirmektedir. Al-Kaisi vd. (2005) ise, organik madde üzerine kısa süreli toprak ișlemenin etkilerinin değișken olduğunu ve değișimlerin yüksek oranda toprak nemi, sıcaklık, oksijen içeriği ve besin elementi içeriği gibi toprak ve çevresel faktörlere bağlı olduğunu rapor etmektedir. Çalıșmanın yürütüldüğü iki yıllık sonuçlar, organik madde içeriğinin toprak ișleme uygulamalarıyla azaldığını ortaya koyarken bu azalma yalnızca 2011 yılında istatistiksel olarak önemli bulunmuștur.

Toprak ișleme uygulamalarının yıllara göre toprak fiziksel özellikleri üzerine olan etkileri ise Çizelge 5'te verilmiștir. Yürütülen tüm toprak ișleme uygulamalarının toplam porozite ve hacim ağırlığı üzerine etkileri her iki yıl için farklı olmuș ve bu farklar istatistiksel olarak önemli bulunmuștur. 2011 yılında 2012 yılına göre topraklarda daha yüksek toplam porozite ve daha düșük hacim ağrlığı değerleri elde edilirken, 2012 yılında elde edilen daha düșük toplam porozite ve daha yüksek hacim ağırlığı değerlerinin, 2012 yılında denemenin yürütüldüğü Mayıs ve Ekim ayları arasındaki yüksek yağıș miktarlarına bağlı olarak meydana gelen yüksek șișme ve büzülme olaylarından kaynaklandığı düșünülmektedir. Toprakların mikropor ve makropor içeriği yönünden toprak ișleme uygulamalarından Doğrudan Ekim uygulaması dıșındaki tüm uygulamaların yıllara göre etkisi istatistiksel olarak önemli bulunmuștur. Organik madde içeriği yönünden ise yalnızca kontrol uygulamasında yıllara göre değișim önemli bulunurken, diğer tüm toprak ișleme uygulamalarında organik maddenin yıllara göre değișimi istatistiksel olarak önemsiz bulunmuștur (Çizelge 5). 
C̣izelge 5. Toprak ișleme uygulamalarının toprak fiziksel özellikleri üzerine yıllara göre etkisi

Table 5. The effect of soil tillage practices on soil physical properties according to years

\begin{tabular}{lllllll}
\hline $\begin{array}{l}\text { Fiziksel } \\
\text { Özellikler }\end{array}$ & YIl & P+2 $\mathrm{D}+2^{*} \mathrm{~F}$ & $\mathrm{AC}+2^{*} \mathrm{D}+2^{*} \mathrm{~F}$ & $\mathrm{P}+2^{*} \mathrm{~F}$ & $\mathrm{DE}$ & Kontrol \\
\hline Toplam & 2011 & $59,60 \pm 0,77 \mathrm{a}$ & $59,11 \pm 0,49 \mathrm{a}$ & $57,79 \pm 0,28 \mathrm{~b}$ & $57,88 \pm 0,42 \mathrm{a}$ & $57.62 \pm 0.39 \mathrm{a}$ \\
Porozite & 2012 & $54,32 \pm 0,28 \mathrm{~b}$ & $54,65 \pm 0,48 \mathrm{~b}$ & $55,86 \pm 0,34 \mathrm{a}$ & $54,62 \pm 0,59 \mathrm{~b}$ & $54.76 \pm 0.55 \mathrm{~b}$ \\
& & $<0,001^{* *}$ & $<0,001^{* *}$ & $0,001^{* *}$ & $0,001^{* *}$ & $0.001^{* *}$ \\
Makropor & 2011 & $6,48 \pm 0,66 \mathrm{~b}$ & $6,55 \pm 0,59 \mathrm{~b}$ & $6,74 \pm 0,60 \mathrm{~b}$ & $7,27 \pm 0,71$ & $6,83 \pm 0,64 \mathrm{~b}$ \\
& 2012 & $10,37 \pm 0,60 \mathrm{a}$ & $9,48 \pm 0,45 \mathrm{a}$ & $8,90 \pm 0,26 \mathrm{a}$ & $7,55 \pm 0,68$ & $8,34 \pm 0,32 \mathrm{a}$ \\
& & $<0,001^{* *}$ & $<0,001^{* *}$ & $0,002^{* *}$ & 0,794 & $0,040^{*}$ \\
Mikropor & 2011 & $53,11 \pm 1,05 \mathrm{a}$ & $52,56 \pm 0,76 \mathrm{a}$ & $51,05 \pm 0,64 \mathrm{a}$ & $50,61 \pm 1,07$ & $50,79 \pm 0,97 \mathrm{a}$ \\
& 2012 & $42,47 \pm 1,11 \mathrm{~b}$ & $45,18 \pm 0,70 \mathrm{~b}$ & $46,96 \pm 0,40 \mathrm{~b}$ & $47,08 \pm 1,23$ & $46,13 \pm 0,76 \mathrm{~b}$ \\
Hacim & 2011 & $1,07 \pm 0,02 \mathrm{~b}$ & $1,08 \pm 0,01 \mathrm{~b}$ & $1,12 \pm 0,01 \mathrm{~b}$ & $1,12 \pm 0,01 \mathrm{~b}$ & $1,12 \pm 0,01 \mathrm{~b}$ \\
Ağırlığı & 2012 & $1,21 \pm 0,01 \mathrm{a}$ & $1,2 \pm 0,013 \mathrm{a}$ & $1,17 \pm 0,01 \mathrm{a}$ & $1,20 \pm 0,02 \mathrm{a}$ & $1,20 \pm 0,02 \mathrm{a}$ \\
& & $<0,001^{* *}$ & $<0,001^{* *}$ & $0,001^{* *}$ & $0,001^{* *}$ & $0,001^{* *}$ \\
Organik & 2011 & $2,64 \pm 0,17$ & $2,25 \pm 0,10$ & $2,34 \pm 0,09$ & $2,58 \pm 0,12$ & $3,31 \pm 0,14 \mathrm{a}$ \\
Madde & 2012 & $2,39 \pm 0,06$ & $2,18 \pm 0,21$ & $1,87 \pm 0,24$ & $2,14 \pm 0,16$ & $2,48 \pm 0,14 \mathrm{~b}$ \\
& & 0,223 & 0,777 & 0,053 & 0,054 & $0,001^{* *}$ \\
\hline
\end{tabular}

$\mathrm{P}+2{ }^{*} \mathrm{D}+2{ }^{*} \mathrm{~F}:$ Pulluk+Diskaro+Freze; $A C+2{ }^{*} \mathrm{D}+2{ }^{*} \mathrm{~F}:$ Ağır Çizel+Diskaro+Freze; $\mathrm{P}+2{ }^{*} \mathrm{~F}:$ Pulluk+Freze; DE: Doğrudan Ekim; *: $\mathrm{p}<$ 0,$05 ; * *: p<0,01$.

Toprak fiziksel özelliklerinin toprak ișleme uygulamalarına göre alansal değișimleri ise jeoistatistiksel analiz yöntemiyle değerlendirilmiș ve elde edilen semivariogram sonuçları Çizelge 6'da, krigleme haritaları ise Sekil 1'de verilmiștir. 2011 ve 2012 yıllarında fiziksel toprak özelliklerinin uzaysal dağılımları küresel model ile tahmin edilirken, elde edilen düșük külçe etkisi değerleri de deneme parselleri içerisinde seçilen örnekleme mesafelerinin toprak özelliklerinin kısa mesafeli değișimlerinin ortaya konulması için uygun olduğunu ortaya koymuștur. Ayrıca toprak ișleme uyglamalarının etkilerinin araștırıldığı her iki yılda da incelenen fiziksel toprak özelliklerinin çalıșma alanında güçlü konumsal ilișkilere sahip olduğu görülmüștür (Çizelge 6).

Toplam porozitenin toprak ișleme uygulamalarına bağı olarak 2011 ve 2012 yıllarına ait dağıım haritası incelendiğinde 2011 yılında

Çizelge 6. Fiziksel toprak özelliklerine ait semivariogram analiz sonuçları

Table 6. The results of semivariogram analysis of physical soil properties

\begin{tabular}{|c|c|c|c|c|c|c|c|}
\hline Fiziksel Özellikler & Model & $\begin{array}{l}\text { Külçe Etkisi } \\
\left(C_{0}\right)\end{array}$ & $\begin{array}{l}\text { Eșik Değeri } \\
\qquad\left(C_{0}+C\right)\end{array}$ & $\begin{array}{c}\text { Yapısal Uzaklık } \\
\qquad\left(\mathrm{A}_{0}\right)\end{array}$ & HKT & $r^{2}$ & Çapraz Doğrulama \\
\hline \multicolumn{8}{|c|}{2011 YIlI } \\
\hline Toplam Porozite & Küresel & 0,001 & 2,674 & 32,3 & 0,041 & 0,99 & 0,81 \\
\hline Makropor & Küresel & 0,01 & 3,929 & 20,34 & 0,23 & 0,98 & 0,74 \\
\hline Mikropor & Küresel & 0,01 & 6,345 & 19,24 & 0,147 & 0,99 & 0,74 \\
\hline Hacim Ağırlığı & Küresel & 0,000 & 0,002 & 30,2 & $2,73 \times 10^{-8}$ & 0,99 & 0,79 \\
\hline OrganikMadde & Küresel & 0,022 & 0,205 & 27,58 & $5,52 \times 10^{-4}$ & 0,96 & 0,80 \\
\hline \multicolumn{8}{|c|}{2012 Yilı } \\
\hline Toplam Porozite & Küresel & 0,01 & 3,283 & 29,18 & 0,156 & 0,98 & 0,82 \\
\hline Makropor & Küresel & 0,199 & 2,148 & 22,29 & 0,023 & 0,99 & 0,72 \\
\hline Mikropor & Küresel & 0,01 & 6,364 & 17,61 & 0,708 & 0,97 & 0,78 \\
\hline Hacim Ağırlığı & Küresel & 0,000 & 0,002 & 30,31 & $1,98 \times 10^{-7}$ & 0,94 & 0,89 \\
\hline OrganikMadde & Küresel & 0,016 & 0,179 & 31,62 & $1,44 \times 10^{-3}$ & 0,88 & 0,71 \\
\hline
\end{tabular}

$\mathrm{P}+2{ }^{*} \mathrm{D}+2{ }^{*} \mathrm{~F}:$ Pulluk+Diskaro+Freze; $\mathrm{ACc}+2{ }^{*} \mathrm{D}+2{ }^{*} \mathrm{~F}:$ Ağır Çizel+Diskaro+Freze; P+2*F: Pulluk+Freze; DE: Doğrudan Ekim; * $\mathrm{p}<$ 0,$05 ; * *: p<0,01$. 
Pulluk+Diskaro+Freze ve Ağır Çizel+Diskaro+Freze uygulamalarında toplam porozite değerlerinin en yüksek olduğu buna karșın Pulluk+Freze, Doğrudan Ekim ve Kontrol uygulamalarında ise düșük değerler aldığı ve krigleme haritasının bu dağıım deseninin Duncan çoklu karșilaștırma sonuçlarıyla benzer olduğu görülmektedir (Șekil 1, Çizelge 4). 2012 ylında ise toprak ișleme uygulamalarının toplam porozite içeriğinde krigleme haritasındaki dağıım desenleri yönünden önemli farklılıklarının olmadığı görülmektedir. 2012 yılında en düșük toplam porozite değerleri tüm deneme parsellerinin kuzey yönlerinde elde edilirken, en yüksek değerler Ağır Çizel+Diskaro+Freze ve Pulluk+Freze uygulamalarının yürütüldüğü deneme parsellerinde elde edilmesine karșın parseller arasındaki bu değișkenliklerin istatistiksel olarak önemli olmadığı görülmektedir (Șekil 1, Çizelge 4).

Makropor içeriğine ait dağılım haritası incelendiğinde, 2011 yılında toprak ișleme uygulamalarının 2012 yılındaki toplam poroziteye ait dağılım desenine benzer bir dağıım sergilediği ve toprak ișleme uygulamalarının makropor içeriğine istatistiksel yönden önemli etkisinin olmadığı buna karșın 2012 yılındaki dağılım deseninde ise toprak ișleme uygulamları yönünden farklı dağı̆ım desenlerinin oluștuğu görülmektedir (Șekil 1). Krigleme haritasının dağılım desenine göre en yüksek makropor içeriği Pulluk+Diskaro+Freze uygulamasında elde edilirken, en düșük makropor dağıımları Doğrudan Ekim ve Kontrol uygulamalarında elde edilmiș ve toprak ișleme uygulamaları arasında gerçekleșen farklı dağılım deseni istatistiksel olarak önemli bulunmuștur (Șekil 1, Çizelge 4).

2011 ve 2012 yıllarında toprak ișleme uygulamalarına bağlı olarak toprakların mikropor içeriğine ait dağılım deseni incelendiğinde birinci ve ikinci yıl arasında tam tersi sonuçların ortaya çıktığı görülmektedir. İlk yıl toprak ișleme uygulamalarına bağlı olarak en yüksek mikropor içeriği Pulluk+Diskaro+Freze uygulamasının yürütüldüğü parselde elde edilirken, ikinci yıl ise bu toprak ișleme uygulamasının yürütüldüğü parsel en düșük değerlerin elde edildiği parsel olmuștur. Yine benzer șekilde ilk yıl en düșük mikropor değerlerinin elde edildiği Doğrudan Ekim ve Kontrol uygulamaları ikinci yıl en yüksek değerlerin elde edildiği uygulamalar olmuștur. Her iki yılda da Pulluk+Diskaro+Freze uygulaması ile Doğrudan
Ekim ve Kontrol uygulamalarının etkileri yıllara göre farklıık gösterirken, toprak ișleme uygulamaları arasında gerçekleșen bu farklı etkiler istatistiksel olarak da önemli bulunmuștur (Șekil 1, Çizelge 4).

Hacim ağırlığının toprak ișleme uygulamalarına bağlı olarak 2011 ve 2012 yıllarına ait krigleme dağılım haritaları incelendiğinde, ilk yıl Pulluk+Diskaro+Freze uygulamasının yürütüldüğü parselde en düșük değerlerini aldığı Pulluk+Freze, Doğrudan Ekim ve Kontrol uygulamalarının yürütüldüğü parsellerde ise en yüksek değerlerini aldığı ve ilk yıl toprak ișleme uygulamaları arasındaki bu farklarında istatistiksel olarak önemli bulunduğu görülmüștür (Șekil 1, Çizelge 4). İkinci yılda ise, toprak ișleme uygulamalarının hacim ağırlığı üzerine olan etkilerinde, dağıım deseni haritasına göre önemli farklılıklar gözlenmemiștir. En düșük hacim ağırlığı değerleri Pulluk+Freze uygulamasının yürütüldüğü parselde bulunurken, diğer toprak ișleme parsellerindeki hacim ağırlığı değerlerinin birbirine yakın olduğu görülmüștür (Șekil 1).

Toprak ișleme uygulamalarının toprakların organik madde içerikleri üzerine olan etkilerine ait krigleme haritaları değerlendirildiğinde ilk yıl en yüksek organik madde içeriğinin Kontrol parselinde elde edildiği görülmüștür. Toprak ișleme uygulamalarının yürütüldüğü parsellerde ise, organik madde içeriği azalmıș ve Kontrol parseli ile toprak ișleme uygulamaları arasında organik madde içeriği yönünden ortaya çıkan bu farklııklar, istatistiksel yönden önemli bulunmuștur (Șekil 1, Çizelge 4). İkinci yılda ise, yine en yüksek organik madde içeriği Kontrol uygulamasında elde edilmiș ve toprak ișleme uygulamalarına göre organik madde içeriğinde azalmalar meydana gelerek en düșük organik madde içeriği Pulluk+Freze uygulamasının yürütüldüğü parsellerde elde edilmiștir. Ancak, ikinci yılda toprak ișleme uygulamalarına bağlı ortaya çıkan değișimler istatistiksel olarak önemsiz bulunmuștur (Șekil 1, Çizelge 4). 


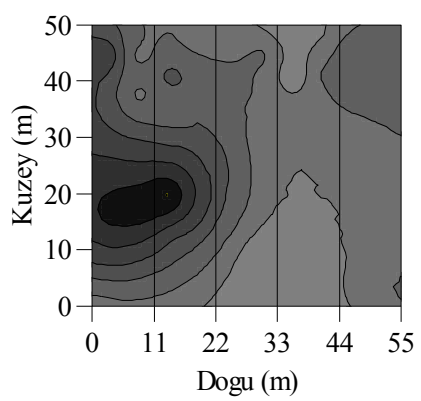

Toplam Porozite_2011
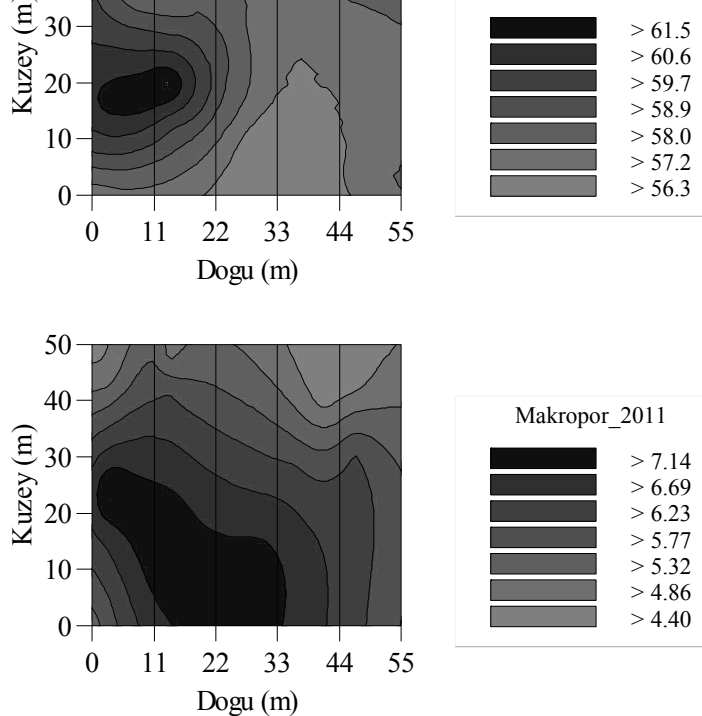

Makropor_2011

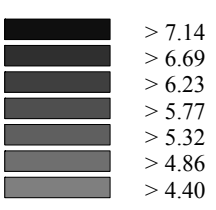

Mikropor_2011
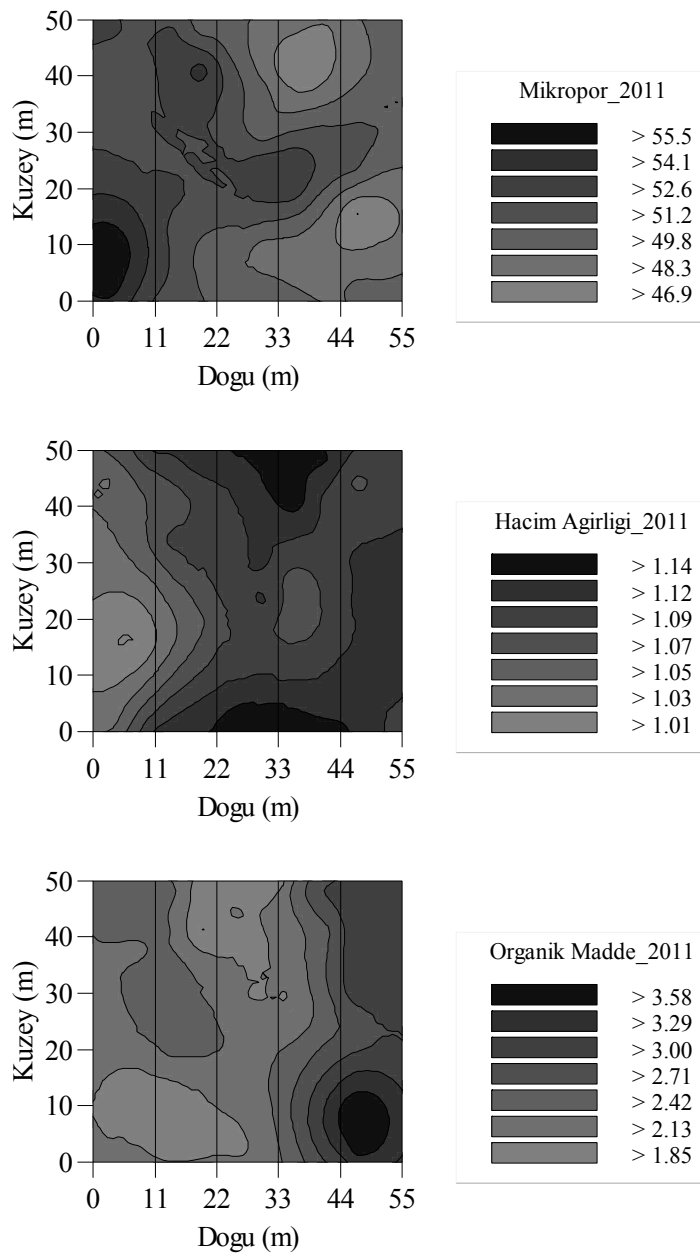

Hacim Agirligi_2011

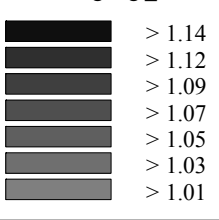

Organik Madde_2011

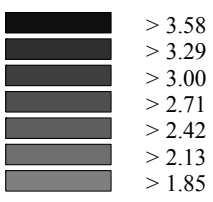

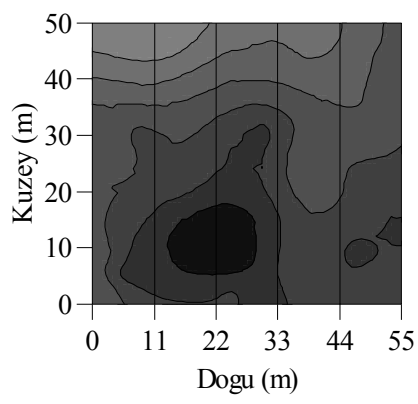

Toplam Porozite_2012
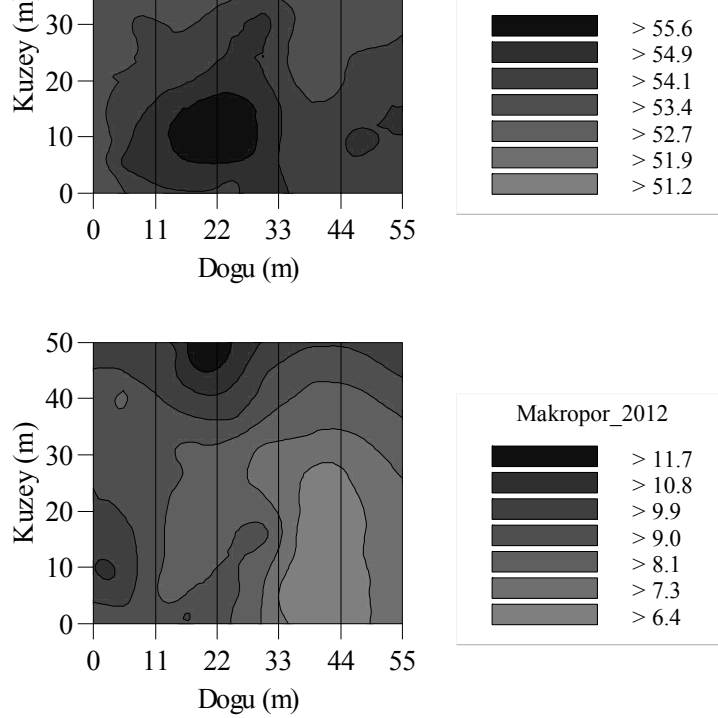

Makropor_2012
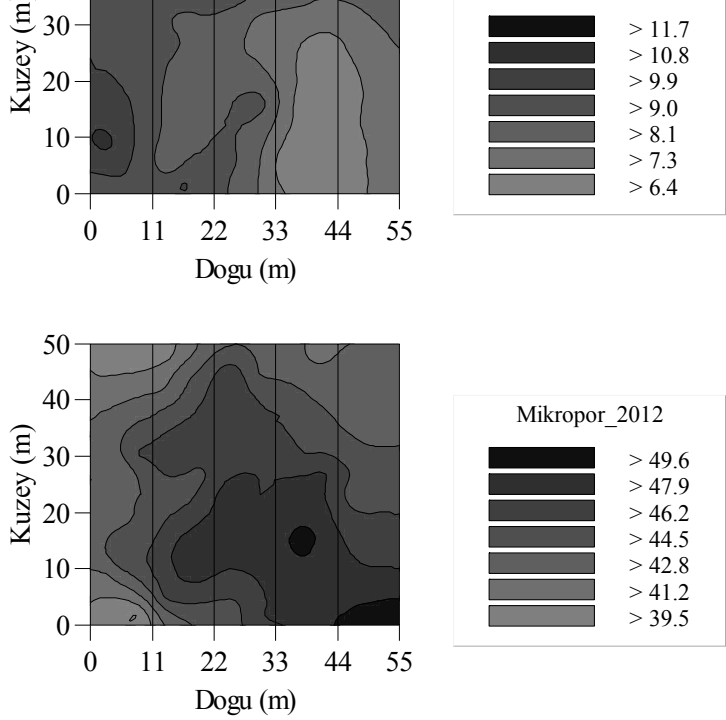

Mikropor_2012

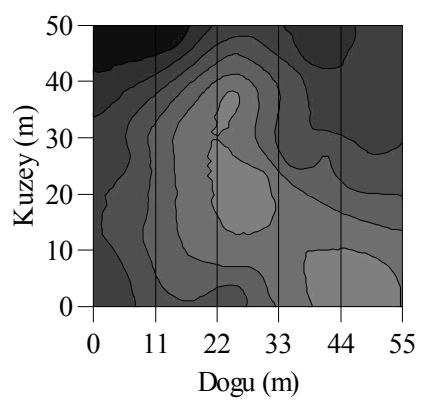

Hacim Agirligi 2012
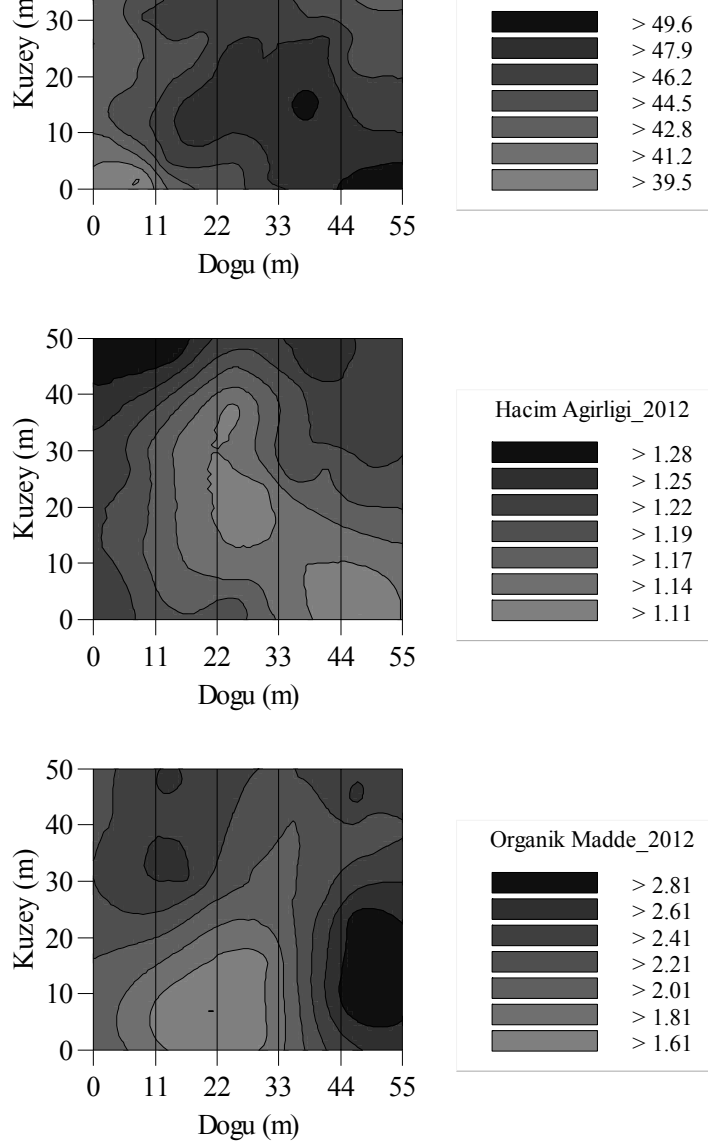

Organik Madde_2012

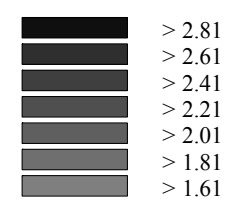

0-11 m: Pulluk+2*Diskaro+2*Freze; $11-22$ m: Ağır Çizel+2*Diskaro+2*Freze; 22-33 m: Pulluk+2*Freze; 33-44 m: Doğrudan Ekim; 44-55 m: Kontrol.

Sekil 1 . Fiziksel toprak özelliklerine ait krigleme haritaları

Figure 1. Kriging maps for physical soil properties 


\section{SONUC}

Farklı toprak ișleme yöntemlerinin ağır killi tekstüre sahip bir toprakta havalanma ve su hareketi ile ilișkili fiziksel toprak özellikler üzerine olan etkilerinin araștırıldığı iki yıllık arazi çalıșmasıyla elde edilen sonuçlar önemli farklılıklar ortaya koymuștur. İlk yıl toprak ișleme uygulamalarının toplam porozite, mikropor içeriği, hacim ağırlığı ve organik madde içeriği üzerine önemli etkileri belirlenirken, makropor içeriğindeki değișimler önemsiz olmuștur. İkinci yıl ise, toprak ișleme uygulamalarının yalnızca makropor ve mikropor içeriklerine etkileri istatistiksel olarak önemli bulunmuștur. İlk yıl Kontrol uygulamasına kıyasla toprak ișleme uygulamalarına bağlı olarak hacim ağırlığı değerlerinin azaldığı ve toprakta gözenekliliğin artarak daha yüksek toplam porozite değerlerinin elde edildiği görülürken, ikinci yılda bu etki gözlemlenmemiștir. İkinci yılda toprak ișleme uygulamalarının etkilerinin farklı olmasının önemli bir nedeninin, ilk yıla oranla ikinci yılda denemenin yürütüldüğü Mayıs ve Ekim ayları arasındaki yağıș rejimindeki farklııklardan kaynaklandığı düșünülmektedir. Benzer șekilde Lal (1989)'de, toprak fiziksel özelliklerindeki değișimin büyüklüğünün ve eğilimlerinin geçmiș koșullara, tarla trafiğine, toprak tekstürüne ve iklime bağlı olduğunu ifade etmektedir. Ayrıca her iki yılda da makropor değerleri üzerine toprak ișleme uygulamalarının etkisi, bitki gelișimi ve iyi drenaj için genel olarak uygun kabul edilen \% 10-15 değerlerinin altında olduğu görülürken, yalnızca 2012 yılındaki Pulluk+Diskaro+Freze uygulamasında makropor içeriğinde bitki gelișimi ve iyi drenaj için uygun koșulların sağlandığı görülmüștür.

Toprak ișleme uygulamalarının etkilerine ait krigleme dağılım haritalarının ise parsel içerisindeki değișkenliklere yönelik önemli bilgileri yansıttığı ve olușan dağılım desenleri ile Duncan çoklu karșılaștırma sonuçlarının birbirini destekler nitelikte olduğu görülmüștür. Bu yönüyle jeoistatistiksel yöntemlerin toprak ișleme gibi yönetimsel uygulamalara bağlı olarak toprak özelliklerinde meydana gelen değișkenliklerin haritalanmasında bașarılı bir șekilde kullanılabileceği ve bu yönüyle de toprak kalitesinin korunmasında ve sürdürülmesinde önemli katkılarının olabileceği düșünülmektedir.

\section{KAYNAKLAR}

Al-Kaisi M, Yin X, Licht M A (2005). Soil carbon and nitrogen changes as affected by tillage system and crop biomass in a corn-soybean rotation. Applied Soil Ecology, 30: 174-191.
Allison LE, Moodie C D (1965). Carbonate. In: C A Black, D D Evans, J L White, L E Ensminger and F E Clark (Eds.), Methods of Soil Analysis, Part II, American Society of Agronomy Inc., No: 9, Madison, Wisconsin, pp. 1379-1400.

Alves M C (1992). Cultivation rotation systems with direct drilling on a red latosol: effect on soil physical and chemical properties. PhD Thesis, Escola Superior Agricultura “Luiz de Queiroz", University of Sao Paulo, Piracicaba, Brazil.

Ankeny M D, Kaspar C K, Horton R (1990). Characterization of tillage effects on unconfined infiltration measurements. Soil Science Society America Journal, 54: 837-840.

Arshad M A, Franzluebbers A J, Azooz R H (1999). Components of surface soil structure under conventional and no-tillage in northwestern Canada. Soil Tillage Research, 53: $41-47$.

Arzeno J L (1990). Physical evaluation of different soil management systems on a red distrophic latosol. PhD Thesis, Escola Superior Agricultura "Luiz de Queiroz", University of SaO Paulo, Piracicaba, Brazil.

Blake G R, Hartge K H (1986). Bulk Density and Particle Density. In: A Klute (Eds.), Methods of Soil Analysis, Part 1, Physical and Mineralogical Methods (2nd ed.), ASA and SSSA Agronomy Monograph, No: 9, Madison, Wisconsin, pp. 363381.

Campos M C C, Marques Júnior J, Pereira G T, Montanari $R$, Siqueira D S (2007). Variabilidade espacial da textura de solos de diferentes materiais de origem em Pereira Barreto, SP. Revista Ciência Agronômica, 38: 149-157.

Campos M C C, Soares M D R, Oliveira A, Santos L A C, Aquino R E (2013). Spatial variability of physical attributes in Alfissol under agroforestry, Humaitá region, Amozonas state, Brazil. Revista Ciência Agronômica, 56 (2): 149-159.

Castro O M (1995). Physical and chemical characteristics on a red latosol as a function of seedbed preparation for maize _Zea mays L. PhD Thesis, Escola Superior Agricultura "Luiz de Queiroz", University of Sao Paulo, Piracicaba, Brazil.

Çetin M, Akbaș T, Șimșek E (2009). Farklı Toprak Iș̦leme Alet ve Makinalarının Toprağın Penetrasyon Direncine Etkilerinin Belirlenmesi. 25. Tarımsal Mekanizasyon Ulusal Kongresi, Isparta.

Danielsen R E, Sutherland P L (1986). Soil porosity. In: A Klute (Ed.), Methods of Soil Analysis, Part 1, Physical and Mineralogical Methods (2nd ed.), ASA and SSSA Agronomy Monograph, No. 9, Madison, Wisconsin, pp. 443-461.

Fabrizzi K P, Garcia F O, Costa J L, Picone L I (2005). Soil water dynamics, physical properties and corn and wheat responses to minimum and no-tillage systems in the southern Pampas of Argentina. Soil Tillage Research, 81: 57-69.

Farkas C, Csaba Gyuricz C, Birkas M (2006). Seasonal changes of hydraulic properties of a Chromic Luvisol under different soil management. Biologia, Bratislava, 61/Suppl., 19: 344-348.

Fernandez-Rueda Ma J, Paz-Gonzalez A (1998). Influence of organic matter content on soil physical properties. Cad. Lab. Xeol. Laxe, 23: 101-120. 
Ferreras L A, Costa J L, Garcia F O, Pecorari C (2000). Effect of no-tillage on some soil physical properties of a structural degraded Petrocalcic Paleudoll of the southern Pampa of Argentina. Soil Tillage Research, 54: 31-39.

Filipovic D, Husnjak S, Kosutic S, Gospodaric Z (2006). Effects of tillage systems on compaction and crop yield of Albic Luvisol in Croatia. Journal of Terramech, 43: 177-189.

Franzluebbers A J, Hons F M, Zuberer D A (1995). Tillage and crop effects on seasonal soil carbon and nitrogen dynamics. Soil Science Society America Journal, 59: 1618-1624.

Freebarin D M, Wockner G H, Silburn D M (1986). Effects of catchment management on runoff, water quality and yield potential from Vertisols. Agricultural Water Management, 12: 119.

Gantzer C J, Blake G R (1978). Physical characteristics of Le Sueur clay loam soil following no-till and conventional tillage. Agronomy Journal, 70: 853-857.

Gee G W, Bauder J W (1 986). Particle-Seize Analysis. In: A Klute (Ed.), Methods of Soil Analysis, Part I, Physical and Mineralogical Methods (2nd ed.), ASA and SSSA Agronomy Monograph, No. 9, Madison, Wisconsin, pp. 388-409.

Gomez J A, Giraldez J V, Pastor M, Fereres E (1999). Effects of tillage methods on soil physical properties, infiltration and yield in an olive orchard. Soil Tillage Research, 52: 167-175.

Hao X, Chang C, Lindwall C W, Bergen P, Conner R L (1999). Crop sequence and reduced tillage to maximize crop production and promote soil conservation under irrigation. Canada-Alberta Environmentally Sustainable Agriculture Agreement Research Program. Final Technical Report Project Number RES-077-94. AAFC Lethbridge Research Centre, Lethbridge, Alta.

Havlin J L, Kissel D E, Maddux L D, Claasen M M, Long J H (1990). Crop rotation and tillage effects on soil organic carbon and nitrogen. Soil Science Society America Journal, 54: 448452.

Hendershot $W H$, Lalande $H$, Duquette M (1993). Soil Reaction and Exchangeable Acidity. In: M R Carter (Ed.), Soil Sampling and Methods of Analysis, Canadian Society of Soil Science, pp. 141-145.

Jackson M L (1 958). Soil chemical analysis. Prentice Hall Inc., Englewood Cliffs, N.J.

Kay B D, Vanden Bygaart A J (2002). Conservation tillage and depth stratification of porosity and soil organic matter. Soil Tillage Research, 66: 107-118.

Kirișçi V, Keskin M, Say S M, Keskin S G (1999). Hassas uygulamalı tarım teknolojisi.

Klute A (1986). Water retention: Laboratory methods. In: A Klute (Eds.) Methods of soil analysis, Part 1, Physical and Mineralogical Methods (2nd ed.), ASA and SSSA Agronomy Monograph, No. 9, Madison, Wisconsin, pp. 635-662.

Korucu T (2002). Cukurova Bölgesinde İkinci Ürün Mısırın Doğrudan Ekim Olanaklarının Araștırıması. Doktora Tezi. Cukurova Üniviversitesi Fen Bilimleri Enstitüsü, Adana.

Lal R, Stewart B A (1990). Soil degradation: a global threat. In: R Lal and B A Stewart (Eds.), Advances in Soil Science, vol. 11, Springer-Verlag, New York, pp. 12-17.
Lal R ( 1989). Conservation tillage for sustainable agriculture: tropics versus temperate environments. Advances in Agronomy, 42: 85-197.

Lal R, Mahboubi A, Fausey N R (1994). Long-term tillage and rotation effects on properties of central Ohio soils. Soil Science Society America Journal, 58: 517-522.

Lipiec J, Kus J, Slowinska-Jurkiewicz A, Nosalewicz A (2006). Soil porosity and water infiltration as influenced by tillage methods. Soil Tillage Research, 89: 210-220.

Logsdon S D, Karlen D L (2004). Bulk density as a soil quality indicator during conversion to no-tillage. Soil Tillage Research, 78: 143-149.

Mahboubi A, Lal R, Fausey N R (1993). Twenty-eight years of tillage effects on two soils on Ohio. Soil Science Society America Journal, 57: 506-512.

Mc Vay K A, Budde J A, Fabrizzi K, Mikha M M, Rice C W, Schlegel A J, Peterson D E, Sweeney D W, Thompson C (2006). Management effects on soil physical properties in long-term tillage studies in Kansas. Soil Science Society America Journal, 70: 434-438.

McGarry D, Bridge B J, Radford B J (2000). Contrasting soil physical properties after zero and traditional tillage of an alluvial soil in the semi-arid subtropics. Soil Tillage Research, 53: 105115.

Mulla D J, McBratney A B (2000). Soil Spatial Variability. In: M E Summer (Ed. in chief), Handbook of Soil Science, CRS Press, A-321-A-351.

Oliver R, Douzet J M, Scopel E, Blanchart E, Curmi P, Alves Moreira J A, Minette S, Guerin P, Fortier M, Maraux F (2002). Medium term impact of no tillage on some physical properties of a Brazilian oxisol of Cerrados (tropical humid savannah of central Brazil). In: F Maraux (Ed.), Confronting New Realities in the 21 st Century. Proceedings of the 17th World Congress of Soil Science.

Paz-Gonzalez A, Guerif J (1993). Texture dependent physical and mechanical properties of soil containing small amounts of swelling material. Invest Agrar., 8(3): 387-410.

Rasmussen K J (1999). Impact of ploughless soil tillage on yield and soil quality: a Scandinavian review. Soil Tillage Research, 53: 3-14.

Rhoades J D (1986). Soluble Salts. In: A Klute (Ed.), Methods of Soil Analysis, Part II, Chemical and Microbiological Properties (2nd ed.), ASA and SSSA Agronomy Monograph, No. 9, Madison, Wisconsin, pp. 167-179.

Salinas-Garcia J R, Hons F M, Matocha J E (1997). Long-term effects of tillage and fertilization on soil organic matter dynamics. Soil Science Society America Journal, 61: 152-159.

Sarvasi F O C (1994). Water dynamics, water erosion and crop productivity as a function of soil preparation. MS Thesis, Escola Superior Agricultura "Luiz de Queiroz", University of Sao Paulo, Piracicaba, Brazil.

Schjønning P, Rasmussen K (2000). Soil strength and soil pore characteristics for direct drilled and ploughed soils. Soil Tillage Research, 57: 69-82.

Singh K K, Colvin T S, Erach D C, Mughal, A Q (1992). Tilth index: an approach quantifying soil tilth. Transactions of American Society of Agricultural Engineers, 35(6): 1777-1 784. 
Sparling G P, Schipper L A (2002). Soil quality at a national scale in New Zealand. Journal of Environmental Quality, 31 : 1848-1857.

Strudley M W, Green T R, Ascough II J C (2008). Tillage effects on soil hydraulic properties in space and time: state of the science. Soil Tillage Research ,99: 4-48.

Tebrügge F, Düring R A (1999). Reducing tillage intensity: a review of results from a long-term study in Germany. Soi Tillage Research, 53: 15-28.

Vidal C M (1997). EvaluacioÂn de algunas propiedades fõÂsicas en sistemas de siembra directay labranza reducida. Tesis de Grado. Facultad de Ciencias Agrarias de Balcarce. UNMdP.
Webster R (2001). Statistics to support soil research and their presentation. European Journal Soil Science, 52: 331-340.

Wilding L P, Bouma J, Goss D W (1994). Impact of Spatial Variability on Interpretative Modelling In: R B Bryant, R W Arnold (Eds.), Quantitative Modelling of Soil Forming Processes. Soil Science Society of American Special Publication Number 39, Soil Science Society of American Inc., Madison, Wisconsin.

Witkowska-Walczak B, Turski M (2004). Porosity and water useful for plants in Luvisols created from sandy silt and silt. International Agrophysics, 18: 189-194. 